\title{
Maternal Perception and Antenatal Advice regarding Fetal Movements in Al-Gharbyia Governorate, Egypt
}

\author{
Ghada Abd El-Salam Belal ${ }^{1}$ and Entisar Abo Elghite Elhossiny Elkazeh ${ }^{2}$ \\ ${ }^{1}$ Lecturer in Maternity and Gynecological Nursing Department, ${ }^{2}$ Assistant professor in Community Health \\ Nursing Department, Faculty of Nursing, Tanta University
}

\begin{abstract}
Background: Maternal perception of fetal movements is a universally implemented self - screening tool, administered and interpreted individually by all pregnant women, with or without guidance from health care professionals. Aim: This study aimed to determine the maternal perception and antenatal advice regarding fetal movements in Al-Gharbyia Governorate, Egypt. Subjects and Method: This study followed a descriptive design. The study was carried out at three Maternal and Child Health Centers affiliated to the different available geographical health zones at Tanta City. The subjects of the study consisted of 300 pregnant women who were selected from the previously mentioned settings. The tool: A structured interview questionnaire sheet was designed to collect the required data, which is comprised of five parts. Part (1) Sociodemographic characteristics, obstetric history, and attendance of antenatal care. Part (2) Maternal perception of fetal movement. Part (3) Knowledge about fetal movement. Part (4) The action that should be taken in case of unusual fetal movement. Part (5) Sources of information about fetal movement and fetal movement advice received during antenatal care. Results: The results indicated that more than two-thirds of the studied women felt that it is easy to feel fetal movement, and most of the studied women had a positive response to baby's first movement. Also, most of the studied women were concerned about fetal movement, and $29 \%$ of them perceive fetal movement best in the early morning. Very limited knowledge was displayed on the number of fetal movements experienced per hour by 5.7\% of the studied women and one-quarter of them knew that it is not normal to experience fewer than 3 movements in 8 hours. Conclusion: One-quarter of the studied women exhibited poor knowledge regarding fetal movement, most of them made the wrong action in case of unusual fetal movements, and more than two-thirds of them did not receive any advice about fetal movements during routine antenatal care. Recommendations: increase maternal awareness about fetal movements and the action that should be taken in case of unusual fetal movements through antenatal classes, pamphlet and mass media particularly during antenatal care.
\end{abstract}

Keywords: Maternal perception, Fetal movement, Knowledge, Antenatal Advice.

\section{Introduction}

Fetal movements have been used to detect pregnancy and indicate ongoing fetal life. They are considered an indirect measure of the integrity and function of the fetal nervous system ${ }^{(1,2)}$. The perception of fetal movements by the mother is highly subjective. Fetal movements follow a rhythmic pattern and are an expression of fetal wellbeing. Mothers usually report fetal movements from about 20 weeks of gestation, with a peak at 28-34 weeks. Multiparous women may fell movements earlier (16-20 weeks) than primiparous women (20-22 weeks) ${ }^{(3)}$. The movements are at first weak and can be difficult to distinguish from intestinal movement. As integration occurs, the movements become more complex, regular, and sustained ${ }^{(3,4)}$.

It has been suggested that a gradual decrease in fetal movement during the third trimester is due to improve fetal coordination, reduced amniotic fluid volume, and increased fetal size. Some ultrasound studies on fetal movement illustrate that these movements do not decrease in the third trimester, but the movements change as coordination develops and a cycle becomes established ${ }^{(5)}$.

Maternal perception of fetal movements differs and depends on many factors as placental position, amniotic fluid volume, fetal sleep state, parity, maternal smoking status, and body habits ${ }^{(6)}$. There is no specific number which represents a "normal" number of fetal movements and the specific time in which those movements occur and maternity healthcare providers should be aware of this when giving advice to the pregnant women ${ }^{(7,8)}$. The counting of fetal movements by the mother has been recommended as a tool for supporting self-screening of mothers for decreasing fetal movements. The daily fetal movements counting may increase the mother's awareness to recognize the warning signs that put the fetus in danger, and then the suitable time for proper intervention ${ }^{(9,10)}$.

Decreased fetal movement (DFM) or an absence of fetal movements for a period of time are considered as an indicator of a fetus at risk for fetal compromise and have been associated with an increased risk of intrauterine fetal death and stillbirth ${ }^{(11,12,13)}$. Stillbirth continues to be a prevalent health issue for families, 
midwives, and other healthcare providers with 1:130 women of 20 weeks gestation or more having a stillborn baby ${ }^{(14)}$. Stillbirth and perinatal morbidity and mortality are devastating for parents and their families, and are associated with psychological, physical, social short and long term adverse effects including depression, anxiety, increased maternal morbidity, suicidal ideation, family disorientation, and social isolation. Furthermore, they are difficult to predict or prevent ${ }^{(15,16)}$. The maternal perception of low fetal movements has been accompanied with increased risk of small for gestational age infants, fetal growth restriction (FGR), and stillbirth ${ }^{(16,17)}$. However, there is an emerging evidence to suggest that an increase in fetal movement (particularly if this is sudden) is also associated with stillbirth ${ }^{(18)}$.

Maternal reaction to a decrease or increase in fetal movements helps in the early detection of high-risk fetuses thus saving baby's life ${ }^{(18)}$. Community health nurses, midwives, obstetricians and other health care providers should routinely provide pregnant women with advice and information about pregnancy related issues including fetal movements, and this topic should be revised in the third trimester of pregnancy ${ }^{(19)}$. Therefore, this study was performed to assess maternal perception and antenatal advice regarding fetal movements that should be received during pregnancy.

\section{Aim of the study}

The present study aimed to assess maternal perception and antenatal advice regarding fetal movements in El-Gharbyia Governorate, Egypt.

Research question:

What is the maternal perception and antenatal advice regarding fetal movements in El- Gharbyia Governorate?

\section{Subjects and Method}

\section{Design:}

A descriptive design was used.

\section{Setting:}

The study was conducted at three Maternal and Child Health Centers affiliated to the different available geographical health zones at Tanta City. The settings were Sager, Boutros and El -Embaby Medical Centers. Subjects:

The study subjects consisted of 300 pregnant women who were selected from the previously mentioned settings. 100 women from each of the three settings were included in the study. Subjects were selected according to the following criteria; more than or equal 28 weeks of gestation, with normal pregnancy, and willing to participate in the study.

The tool of the study: -

A structured interview questionnaire sheet was designed to collect the required data regarding the study elements. It comprised five parts; Part (1): Socio-demographic characteristics, obstetric history and attendance of antenatal care which included age, residence, the level of education, maternal occupation, parity, gestational age, time of initial antenatal care visit, and the number of antenatal visits. Part (2): Maternal perception of fetal movement. It encompassed of 11 questions such as: is it easy to feel fetal movement? the first fetal movement perceived, and perception of unusual fetal movement. Part (3): Knowledge of the pregnant women about fetal movement. It comprised 20 questions such as: when should you feel the fetal movement for the first time? , number of fetal movement per hour, is it normal to experience fewer than 10 movements in 3 hours?, and were fetal movements should be felt during the first trimester? The scoring system of the answers was one for the correct answer and zero for the wrong answer. Then the total score of knowledge was as follows: good level of knowledge $\geq 75 \%$, a fair level of knowledge $50 \%-<75 \%$ and poor level of knowledge < 50\%. Part (4): It included one question about the action that should be taken in case of unusual fetal movement. We asked women what (if anything) they had done following the perception of unusual fetal movements. A correct response (right action) indicated timely contact with a health care provider / lying down / having warm bath /eating /monitoring the movement. Incorrect response (wrong action) indicated the lack of contact with a health care provider for more than 24 hours / waiting for the next antenatal appointment /not doing anything / trying to rationalize the unusual movement. Part (5): The sources of information about fetal movement and advice received during routine antenatal care. It comprised questions such as sources of information about fetal movement during pregnancy, and have you ever been asked about fetal movements during your routine antenatal appointments?

Method:

An official letter was directed from the Faculty of Nursing, Tanta University to the Ministry of Health administrative authorities in order to obtain their acceptance to collect necessary data from the selected settings. Then, the permission was obtained from the center's administrative authorities. The study tool was developed after reviewing the related literature. Validation of the tool was assessed by presenting it to five experts from the 
faculty members in Nursing College, Tanta University, three members of Obstetrics and Gynecology Nursing and two members from Community Health Nursing. The experts were asked to evaluate tools relevance and appropriateness on 4 point rating scales as: $1=$ not relevant, $2=$ little relevant, $3=$ relevant and $4=$ very relevant. Opinions of the experts the tools of the study were analyzed and determined the following: face validity $95.28 \%$, content validity index (CVI) $100 \%$, and internal consistency reliability (coefficient alpha) was applied (á=0.91).

A pilot study was carried out on $10 \%$ of the study samples who were selected to evaluate the clarity and applicability of the research tool. They were excluded from the total sample, and necessary modifications were done based on their responses. Informed consent was obtained from each pregnant woman. The participants informed about the confidentiality of their responses, the free of participation and right to refuse to participate in the study were emphasized. The researchers explained the aim of the study to the participant by written explanation in the covering letter of the questionnaire. The questionnaire was collected through structured interview; the researchers explained the questionnaire to the subjects and then, asked them to complete it. Data were collected by the researchers during the period from July to October 2016.

\section{Statistical analysis:}

Data was collected, coded and organized into tables, and then analyzed using the statistical package for social science (SPSS version 17). Descriptive measures, including frequency, percentage, arithmetic mean and standard deviation were presented. ANOVA test was used for statistical correlation. $\mathrm{P}$ values of $<0.05$ were considered statistically significant.

\section{Results}

Table (1): Distribution of the studied women according to their socio-demographic characteristics

\begin{tabular}{|c|c|c|}
\hline \multirow[t]{2}{*}{ Sociodemographic characteristics } & \multicolumn{2}{|c|}{$\begin{array}{l}\text { The studied women } \\
(\mathrm{n}=\mathbf{3 0 0})\end{array}$} \\
\hline & $\overline{\mathbf{N}}$ & $\%$ \\
\hline $\begin{array}{l}\frac{\text { Age in years: }}{2} \\
\\
-\quad 335 \\
\geq 35\end{array}$ & $\begin{array}{l}274 \\
26\end{array}$ & $\begin{array}{c}91.3 \\
8.7\end{array}$ \\
\hline $\begin{array}{l}\text { Range } \\
\text { Mean } \pm \text { SD }\end{array}$ & & \\
\hline \begin{tabular}{ll}
\multicolumn{2}{l}{ Marital status } \\
- & Married \\
- & Divorced \\
- & Widow
\end{tabular} & $\begin{array}{c}297 \\
1 \\
2\end{array}$ & $\begin{array}{l}99.0 \\
0.3 \\
0.7\end{array}$ \\
\hline $\begin{array}{ll}\text { Residence } \\
& \text { Urban } \\
\text { - } & \text { Rural } \\
\end{array}$ & $\begin{array}{l}124 \\
176\end{array}$ & $\begin{array}{l}41.3 \\
58.7 \\
\end{array}$ \\
\hline $\begin{array}{ll}\text { Educational level } \\
\text { - } & \text { Illiterate } \\
\text { - } & \text { Primary / Prite } \\
\text { - } & \text { Secondary/technical diploma } \\
\end{array}$ & $\begin{array}{c}14 \\
21 \\
30 \\
112 \\
123\end{array}$ & $\begin{array}{c}4.7 \\
7.0 \\
10.0 \\
37.3 \\
41.0\end{array}$ \\
\hline $\begin{array}{ll}\text { Maternal employment } \\
\text { - No } \\
\text { - } \quad \text { Yes }\end{array}$ & $\begin{array}{c}215 \\
85\end{array}$ & $\begin{array}{l}71.7 \\
28.3\end{array}$ \\
\hline \begin{tabular}{ll}
\multicolumn{2}{l}{ Family income } \\
& Not enough \\
- $\quad$ Enough \\
$\quad$ Enough and save
\end{tabular} & $\begin{array}{c}49 \\
212 \\
39\end{array}$ & $\begin{array}{l}16.3 \\
70.7 \\
13.0\end{array}$ \\
\hline
\end{tabular}

Table (1): Presents the distribution of the studied women according to their socio-demographic characteristics. It was found that $91.3 \%$ of the studied women were less than 35 years old, $58.7 \%$ were living in rural areas, $41 \%$ of them had the university education and $71.1 \%$ of the studied women were housewives.

Table (2): Distribution of the studied women according to their obstetric history.

\begin{tabular}{|l|c|c|}
\hline \multicolumn{2}{|c|}{ Obstetrical history } & \multicolumn{2}{|c|}{ The studied women $(\mathbf{n}=\mathbf{3 0 0})$} \\
\cline { 2 - 3 } & $\mathbf{N}$ & $\mathbf{\%}$ \\
\hline Smoking during pregnancy: & 289 & 96.3 \\
\hline$\quad$ No & 11 & 3.7 \\
\hline Pes & & 31.7 \\
\hline Parity & 95 & 62.3 \\
Null & 187 & 6.0 \\
\hline
\end{tabular}


Maternal Perception and Antenatal Advice regarding Fetal Movements in Al-Gharbyia .

\begin{tabular}{|c|c|c|}
\hline $\begin{array}{l}\text { Range } \\
\text { Mean } \pm \text { SD }\end{array}$ & \multicolumn{2}{|c|}{$\begin{array}{c}(0-6) \\
1.42 \pm 1.269 \\
\end{array}$} \\
\hline $\begin{array}{l}\text { Gestational age (weeks) } \\
\text { - } \quad<32 \\
\text { - } \quad \geq 32 \text { years }\end{array}$ & $\begin{array}{l}165 \\
135\end{array}$ & $\begin{array}{c}55.0 \\
45.0\end{array}$ \\
\hline $\begin{array}{l}\text { Range } \\
\text { Mean } \pm \text { SD }\end{array}$ & \multicolumn{2}{|c|}{$\begin{array}{c}(12-42) \\
28.70 \pm 8.301\end{array}$} \\
\hline $\begin{array}{ll}\text { Time of initial antenatal care visit } \\
\text { - } & \text { First trimester } \\
\text { - } & \text { Second trimester } \\
\text { - } \quad \text { Third trimester } \\
\end{array}$ & $\begin{array}{c}259 \\
29 \\
12 \\
\end{array}$ & $\begin{array}{c}86.3 \\
9.7 \\
4.0 \\
\end{array}$ \\
\hline $\begin{array}{ll}\text { Number of antenatal visits } \\
\text { - } & \text { Once } \\
\text { - } & \text { Twice } \\
\text { - } & \text { Three times } \\
\text { - } \quad \text { Four times } \\
\text { - } \quad \text { More than four } \\
\end{array}$ & $\begin{array}{l}19 \\
27 \\
46 \\
16 \\
\quad 192 \\
\end{array}$ & $\begin{array}{c}6.3 \\
9.0 \\
15.3 \\
5.3 \\
64.0 \\
\end{array}$ \\
\hline \begin{tabular}{ll}
\multicolumn{2}{l}{ Planned pregnancy } \\
- $\quad$ Yes \\
- $\quad$ No \\
\end{tabular} & $\begin{array}{c}230 \\
70\end{array}$ & $\begin{array}{l}76.7 \\
23.3\end{array}$ \\
\hline
\end{tabular}

Table (2): Shows the distribution of the studied women according to their obstetric history. It was noticed that more than two-thirds of the studied women $(62.3 \%)$ were a pregnant one to three times, more than half $(55 \%)$ of them were less than 32 weeks gestation and most of them $(86.3 \%)$ sought initial antenatal visit at the first trimester. The table also shows that about two-thirds $(64.0 \%)$ of the studied women had more than four antenatal visits during current pregnancy, and $76.7 \%$ of the studied women their pregnancy was planned.

Table (3): Distribution of the studied women according to their perception of fetal movement

\begin{tabular}{|c|c|c|}
\hline \multirow[t]{2}{*}{ Perception of fetal movement } & \multicolumn{2}{|c|}{$\begin{array}{c}\text { The studied women } \\
(n=300)\end{array}$} \\
\hline & $\overline{\mathbf{N}}$ & $\%$ \\
\hline $\begin{array}{ll}\text { 1. Is it easy to feel fetal movement? } \\
& \text { No } \\
\text { Don't know } \\
\quad \text { Yes }\end{array}$ & $\begin{array}{c}48 \\
57 \\
195\end{array}$ & $\begin{array}{l}16.0 \\
19.0 \\
65.0\end{array}$ \\
\hline $\begin{array}{l}\text { 2. Perception of fetal movement first time by weeks } \\
\text { Range } \\
\text { Mean } \pm \text { SD }\end{array}$ & & 907 \\
\hline $\begin{array}{ll}\text { 3. } & \text { First fetal movement perceived } \\
& \text { Gentle } \\
\text { - } & \text { Gas } \\
\text { Flutter }\end{array}$ & $\begin{array}{l}150 \\
55 \\
95\end{array}$ & $\begin{array}{l}50.0 \\
18.3 \\
31.7\end{array}$ \\
\hline $\begin{array}{ll}\text { 4.Emotional response to feeling baby's first movement } \\
& \text { Negative } \\
\text { - } & \text { Positive } \\
\text { Neutral }\end{array}$ & $\begin{array}{c}26 \\
266 \\
8\end{array}$ & $\begin{array}{c}8.7 \\
88.7 \\
2.7\end{array}$ \\
\hline $\begin{array}{l}\text { 5. Perception of the type of first fetal action } \\
\quad \text { Limp } \\
\text { Whole body } \\
\text { Don't know }\end{array}$ & $\begin{array}{c}116 \\
36 \\
148\end{array}$ & $\begin{array}{l}38.7 \\
12.0 \\
49.3\end{array}$ \\
\hline $\begin{array}{ll}\text { 6.Concern about your fetus movement } \\
\quad \text { No } \\
\quad \text { Yes }\end{array}$ & $\begin{array}{c}22 \\
278\end{array}$ & $\begin{array}{c}7.3 \\
92.7\end{array}$ \\
\hline $\begin{array}{l}\text { 7.Concern if your fetal movement was excessive } \\
\quad \text { No } \\
\text { Yes }\end{array}$ & $\begin{array}{l}157 \\
143\end{array}$ & $\begin{array}{l}52.3 \\
47.7\end{array}$ \\
\hline $\begin{array}{l}\text { 8.Concern if your fetal movement reduced } \\
\quad \text { No } \\
\text { Yes }\end{array}$ & $\begin{array}{c}57 \\
243\end{array}$ & $\begin{array}{l}19.0 \\
81.0\end{array}$ \\
\hline $\begin{array}{l}\text { 9.Perception of unusual fetal movement } \\
\text { Absent fetal movement. } \\
\text { : } \quad \text { Unsure } \\
\text { Excessive fetal movement } \\
\text { Abdominal pain with tingling }\end{array}$ & $\begin{array}{c}186 \\
100 \\
6 \\
8\end{array}$ & $\begin{array}{c}62.0 \\
33.3 \\
2.0 \\
2.7\end{array}$ \\
\hline $\begin{array}{ll}\text { 10.Time of increased perception of fetal movement } \\
& \text { While sitting } \\
\text { - } & \text { While lying down } \\
\text { - } & \text { During exercise food consumption } \\
\text { While feeling hungry }\end{array}$ & $\begin{array}{l}45 \\
162 \\
22 \\
34 \\
37\end{array}$ & $\begin{array}{l}15.0 \\
54.0 \\
7.3 \\
11.3 \\
12.3\end{array}$ \\
\hline
\end{tabular}


Table (3): Reveals the distribution of the studied women according to their perception of fetal movement. It was noticed that about two-thirds of the studied women $(65.0 \%)$ felt that it was easy to feel fetal movement, half of them $(50.0 \%)$ described their first fetal movement as a gentle movement, and most of the studied women $(88.7 \%$ ) had a positive response to baby's first movement. Also, most of the studied women $(92.7 \%)$ were concerned about fetal movement, more than half of them $(52.3 \%)$ were not concerned if the fetal movement was excessive, while $81.1 \%$ of them were concerned if the fetal movement reduced and $54 \%$ of the studied women best perceive fetal movement while lying down.

Figure (1): Distribution of the studied women according to the best time of the day to feel fetal movement

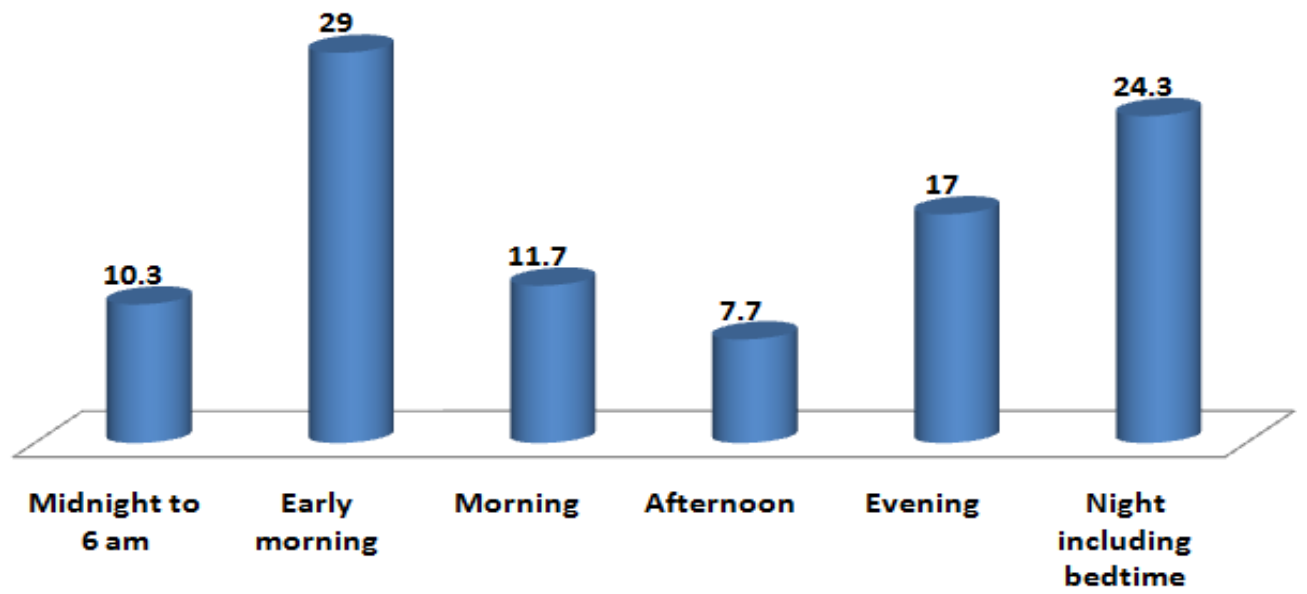

Figure (1): Presents the distribution of the studied women according to the best time of the day to feel fetal movement. It was observed that $29 \%$ of the studied women perceive fetal movement best in the early morning, $24.3 \%$ of them perceive fetal movement best in the night including bedtime, and $17 \%$ perceive it best in the evening.

Figure (2): Distribution of the studied women according to maternal perception of first fetal movement by

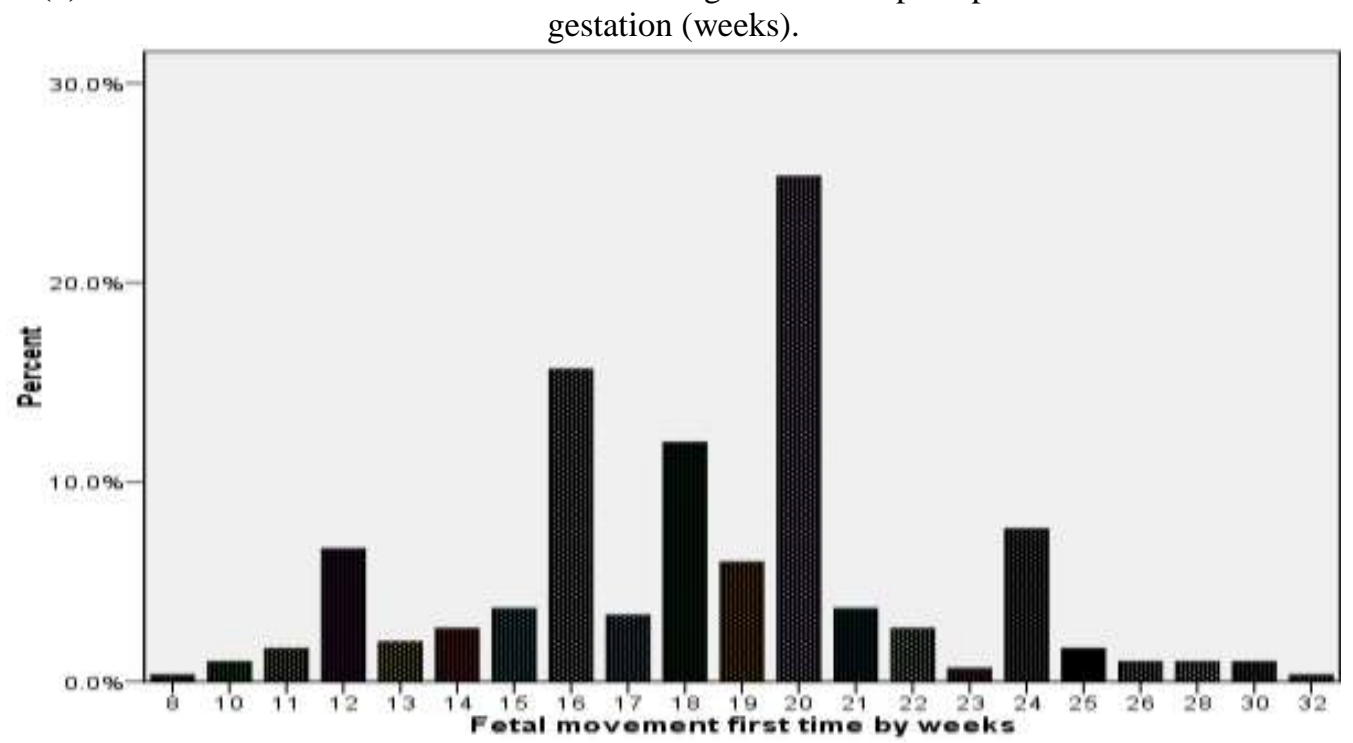

Figure (2): Shows the distribution of the studied women according to maternal perception of first fetal movement by gestation (weeks). It was demonstrated that the earliest reported perception of fetal movements was at 8 weeks and the latest was at 32 weeks. A quarter of the studied women experienced their first fetal movement at 20 weeks $(25.3 \%), 15.7 \%$ of them experienced them at 16 weeks and $12 \%$ of the studied women experienced first fetal movement at 18 weeks. 
Maternal Perception and Antenatal Advice regarding Fetal Movements in Al-Gharbyia .

Table (4): Distribution of the studied women according to their knowledge regarding fetal movement.

\begin{tabular}{|c|c|c|c|c|}
\hline \multirow{3}{*}{ Knowledge regarding fetal movement } & \multicolumn{4}{|c|}{ The studied women $(n=300)$} \\
\hline & \multicolumn{2}{|c|}{ Correct } & \multicolumn{2}{|c|}{ Incorrect } \\
\hline & $\mathbf{N}$ & $\%$ & $\mathbf{N}$ & $\%$ \\
\hline 1. When should you feel fetal movement for the first time? & 216 & 72.0 & 84 & 28.0 \\
\hline 2. Is it important to perceive/feel fetal movement during pregnancy? & 255 & 85.0 & 45 & 15.0 \\
\hline 3. Why is it important to perceive fetal movement? & 232 & 77.3 & 68 & 22.7 \\
\hline 4. Type of the fetal movement experienced? & 187 & 62.3 & 113 & 37.7 \\
\hline 5. A number of fetal movements per hour. & 17 & 5.7 & 283 & 94.3 \\
\hline 6. Is it normal to experience fewer than 10 movements in 3 hours? & 51 & 17.0 & 249 & 83.0 \\
\hline 7. Is it normal to experience fewer than 3 movements in 8 & 73 & 24.3 & 227 & 75.7 \\
\hline 8. Were fetal movements should be felt during the first trimester? & 149 & 49.7 & 151 & 50.3 \\
\hline 9. Is it important to feel fetal movement near the time of delivery? & 231 & 77.0 & 69 & 23.0 \\
\hline 10. Is it important to feel fetal movement daily? & 199 & 66.3 & 101 & 33.7 \\
\hline 11. Is absence of fetal movements in the morning requires immediate action? & 150 & 50.0 & 150 & 50.0 \\
\hline 12. Do pain medications affect fetal movement? & 185 & 61.7 & 115 & 38.3 \\
\hline 13. Does smoking affect fetal movement? & 249 & 83.0 & 51 & 17.0 \\
\hline 14. Do sounds affect fetal movement? & 233 & 77.7 & 67 & 22.3 \\
\hline 15. Does fetal sleep pattern affect his movement? & 197 & 65.7 & 103 & 34.3 \\
\hline 16. Does time of the day affect the perception of fetal movement? & 154 & 51.3 & 146 & 48.7 \\
\hline 17. Does maternal activity level affect the perception of fetal movement? & 168 & 56.0 & 132 & 44.0 \\
\hline 18. Does maternal weight affect the perception of fetal movement? & 173 & 57.7 & 127 & 42.3 \\
\hline 19. Do medications affect the perception of fetal movement? & 251 & 83.7 & 49 & 16.3 \\
\hline 20. Methods of fetal movement counting? & 22 & 7.3 & 278 & 92.7 \\
\hline $\begin{array}{c}\text { Total knowledge score } \\
\text { Range } \\
\text { Mean } \pm \text { SD }\end{array}$ & & & $\begin{array}{l}19) \\
=2.769\end{array}$ & \\
\hline
\end{tabular}

Table (4): Presents the distribution of the studied women according to their knowledge regarding fetal movement. It was noticed that more than three-quarters of the studied women expressed that it is important to feel the fetal movements ( $85 \%$ ), $77.3 \%$ of the studied women reasoned that this is an indication that the baby is alive (accurate response). Very limited knowledge was displayed on the number of fetal movements experienced per hour by $5.7 \%$ of the studied women, while only $17 \%$ indicated that it is not normal to experience fewer than 10 movements in 3 hours and nearly one-quarter $(24.3 \%)$ of the studied women knew that it is not normal to experience fewer than 3 movements in 8 hours. It is also noticed that $77 \%$ and $66.3 \%$ of the studied women, respectively, knew that it is important to feel fetal movements near the time of delivery and the importance of feeling fetal movement daily. 
Figure (3): Distribution of the studied women according to their total knowledge score regarding fetal movement.

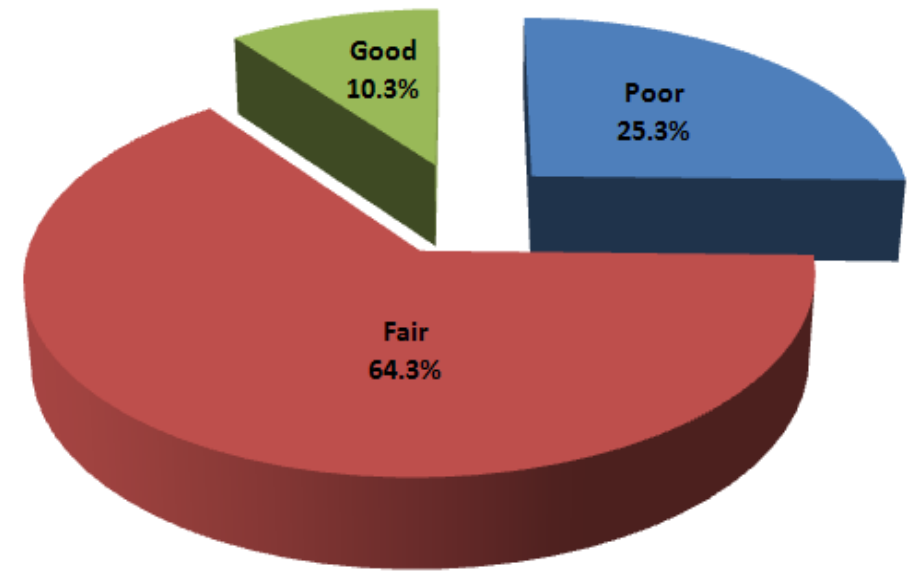

Figure (3): Reveals the distribution of the studied women according to their total knowledge score regarding fetal movement. It was noticed that about one-quarter $(25.3 \%)$ of the studied women exhibited poor knowledge regarding fetal movement compared to about two-thirds of the women (64.3\%) who had a fair knowledge, while only $10.3 \%$ of the studied women had good knowledge about fetal movements.

Table (5): Distribution of the studied women according to their action in case of unusual fetal movement.

\begin{tabular}{|c|c|c|}
\multirow{2}{*}{ Action } & \multicolumn{2}{|c|}{$\begin{array}{c}\text { The studied women } \\
(\mathbf{n}=\mathbf{3 0 0})\end{array}$} \\
\cline { 2 - 3 } & $\mathbf{N}$ & $\mathbf{\%}$ \\
\hline Wrong action & 264 & 88.0 \\
\hline Right action & 36 & 12.0 \\
\hline Range & \multicolumn{2}{|c|}{$\mathbf{( \mathbf { 0 - 6 } )} \mathbf{1 . 3 8 \pm \mathbf { 1 . 0 2 9 }}$} \\
\hline
\end{tabular}

Table (5): Presents the distribution of the studied women according to their action in case of unusual fetal movement. It was noticed that most of the studied women (88\%) made the wrong action in case of unusual fetal movements, while only $12 \%$ of the studied women made the right action.

Figure (4): Distribution of the studied women according to the sources of information regarding fetal movement.

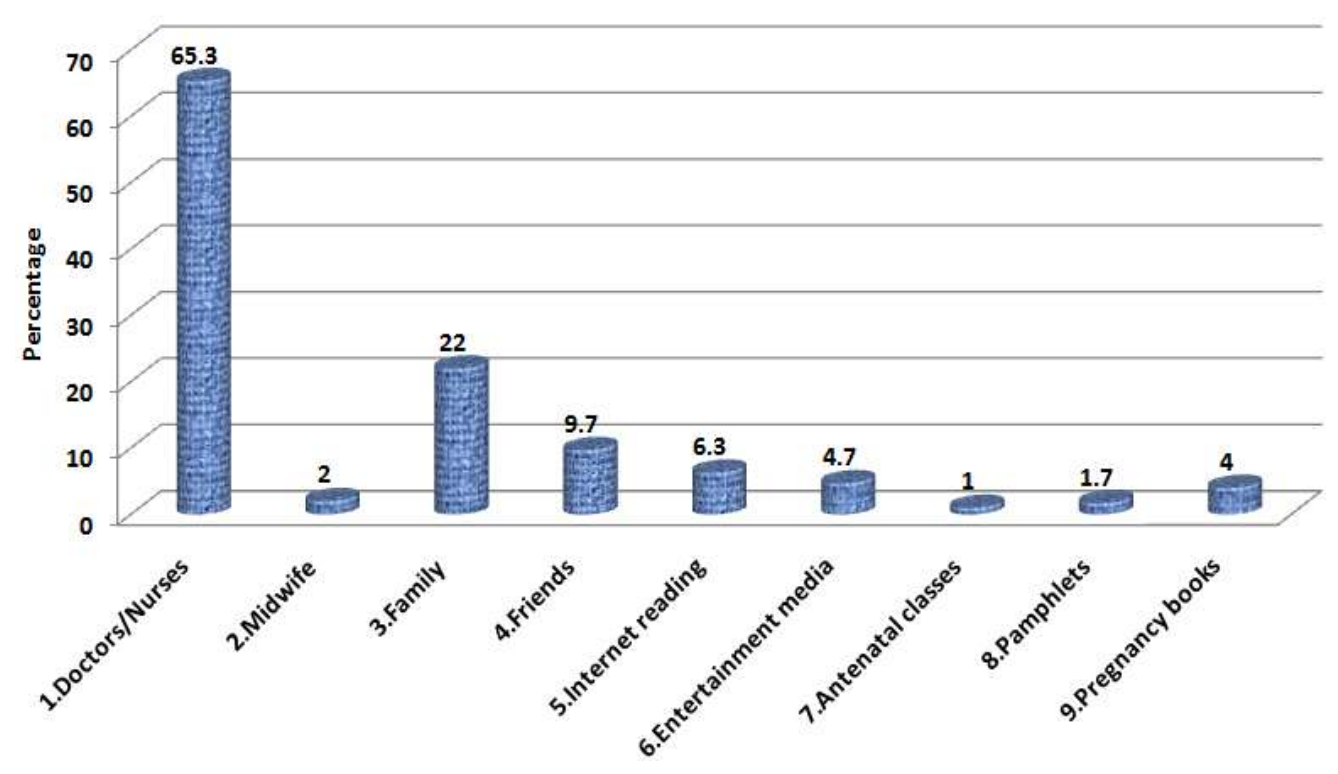

Figure (4): Shows the distribution of the studied women according to the sources of information regarding fetal movement. The figure reveals that about two-thirds of the studied women (65.3\%) mentioned doctor /nurses as 
the source of information regarding fetal movement, $22 \%$ of the studied women mentioned family and $9.7 \%$ of the studied women mentioned friends as the source of information regarding fetal movement.

Table (6): Distribution of the studied women according to the advice received about fetal movements during the routine antenatal care.

\begin{tabular}{|c|c|c|}
\hline \multirow[t]{2}{*}{ Advice received } & \multicolumn{2}{|c|}{$\begin{array}{c}\text { The studied women } \\
(\mathbf{n}=300)\end{array}$} \\
\hline & $\mathbf{N}$ & $\%$ \\
\hline $\begin{array}{l}\text { Did you received advice about Fetal movement ? } \quad(n=300) \\
\text { - } \quad \text { Yes } \\
\text { - } \quad \text { No }\end{array}$ & $\begin{array}{l}114 \\
186\end{array}$ & $\begin{array}{l}38.0 \\
62.0\end{array}$ \\
\hline $\begin{array}{ll}\text { *Advice received about fetal movement }(\mathbf{n = 1 1 4}) \\
\text { - } & \text { Did you feel fetal movement } \\
\text { - } & \text { First time to feel fetal movement } \\
\text { - } & \text { Form of fetal movement } \\
\text { - } & \text { Rate of fetal movement/day } \\
\end{array}$ & $\begin{array}{c}74 \\
11 \\
23 \\
30 \\
8\end{array}$ & $\begin{array}{c}24.7 \\
3.7 \\
7.7 \\
10.0 \\
2.7\end{array}$ \\
\hline
\end{tabular}

* More than one answer

Table (6): Presents the distribution of the studied women according to the advice received about fetal movements during the routine antenatal care. It was observed that about two-thirds of the studied women $(62 \%)$ did not receive any advice about fetal movements during routine antenatal care. Out of those who received advice about fetal movements, $24.7 \%$ of the studied women were asked if they feel fetal movements or not, $7.7 \%$ were asked about the form of fetal movement and only $2.7 \%$ were advised about the action that should be taken in case of unusual fetal movements.

Table (7): Correlation between sociodemographic characteristics of the studied women and their total knowledge score regarding fetal movement.

\begin{tabular}{|c|c|c|c|c|c|c|c|}
\hline \multirow{3}{*}{$\begin{array}{l}\text { Sociodemographic } \\
\text { characteristics }\end{array}$} & \multicolumn{6}{|c|}{ Total knowledge score } & \multirow{3}{*}{$\begin{array}{l}\chi^{2} \\
P\end{array}$} \\
\hline & \multicolumn{2}{|c|}{$\begin{array}{c}\text { Poor } \\
(n=76)\end{array}$} & \multicolumn{2}{|c|}{$\begin{array}{c}\text { Fair } \\
(n=193)\end{array}$} & \multicolumn{2}{|c|}{$\begin{array}{c}\text { Good } \\
(n=31)\end{array}$} & \\
\hline & $\mathbf{N}$ & $\%$ & $\mathbf{N}$ & $\%$ & $\mathbf{N}$ & $\%$ & \\
\hline $\begin{array}{l}\text { Age in years } \\
\text { - } \quad<35 \text { years } \\
\text { - } \quad 35 \text { years }\end{array}$ & $\begin{array}{c}71 \\
5 \\
\end{array}$ & $\begin{array}{c}93.4 \\
6.6 \\
\end{array}$ & $\begin{array}{c}176 \\
17\end{array}$ & $\begin{array}{c}91.2 \\
8.8\end{array}$ & $\begin{array}{c}27 \\
4\end{array}$ & $\begin{array}{l}87.1 \\
12.9 \\
\end{array}$ & $\begin{array}{l}1.126 \\
0.569\end{array}$ \\
\hline \begin{tabular}{ll}
\multicolumn{2}{l}{ Marital status } \\
& Married \\
- & Divorced \\
& Widow
\end{tabular} & $\begin{array}{c}74 \\
0 \\
2 \\
\end{array}$ & $\begin{array}{c}97.4 \\
0.0 \\
2.6\end{array}$ & $\begin{array}{c}192 \\
1 \\
0\end{array}$ & $\begin{array}{c}99.5 \\
0.5 \\
0.0\end{array}$ & $\begin{array}{c}31 \\
0 \\
0\end{array}$ & $\begin{array}{c}100.0 \\
0.0 \\
0.0\end{array}$ & $\begin{array}{l}6.477 \\
0.166\end{array}$ \\
\hline \begin{tabular}{ll}
\multicolumn{2}{l}{ Residence } \\
- & Urban \\
- & Rural
\end{tabular} & $\begin{array}{l}30 \\
46 \\
\end{array}$ & $\begin{array}{l}39.5 \\
60.5 \\
\end{array}$ & $\begin{array}{c}79 \\
114 \\
\end{array}$ & $\begin{array}{l}40.9 \\
59.1\end{array}$ & $\begin{array}{l}15 \\
16\end{array}$ & $\begin{array}{l}48.4 \\
51.6 \\
\end{array}$ & $\begin{array}{l}0.757 \\
0.685\end{array}$ \\
\hline $\begin{array}{ll}\text { Educational level } \\
\text { - } & \text { Illiterate } \\
\text { - } & \text { Reads and writes } \\
\text { - } & \text { Primary / Preparatory } \\
\text { - } & \text { Secondary/technical diploma } \\
\end{array}$ & $\begin{array}{c}4 \\
14 \\
6 \\
31 \\
21 \\
\end{array}$ & $\begin{array}{c}5.3 \\
18.4 \\
7.9 \\
40.8 \\
27.6 \\
\end{array}$ & $\begin{array}{c}10 \\
7 \\
20 \\
72 \\
84 \\
\end{array}$ & $\begin{array}{c}5.2 \\
3.6 \\
10.4 \\
37.3 \\
43.5\end{array}$ & $\begin{array}{c}0 \\
0 \\
4 \\
9 \\
18\end{array}$ & $\begin{array}{c}0.0 \\
0.0 \\
12.9 \\
29.0 \\
58.1\end{array}$ & $\begin{array}{c}28.336 \\
0.00 *\end{array}$ \\
\hline $\begin{array}{ll}\text { Maternal occupation } \\
\text { - } & \text { No } \\
\text { - } & \text { Yes }\end{array}$ & $\begin{array}{l}54 \\
22 \\
\end{array}$ & $\begin{array}{l}71.1 \\
28.9 \\
\end{array}$ & $\begin{array}{c}148 \\
45\end{array}$ & $\begin{array}{l}76.7 \\
23.3\end{array}$ & $\begin{array}{l}13 \\
18\end{array}$ & $\begin{array}{l}41.9 \\
58.1\end{array}$ & $\begin{array}{c}15.902 \\
0.00 *\end{array}$ \\
\hline \begin{tabular}{ll}
\multicolumn{2}{l}{ Family income } \\
\\
- & Not enough \\
Enough \\
\end{tabular} & $\begin{array}{c}18 \\
51 \\
7\end{array}$ & $\begin{array}{c}23.7 \\
67.1 \\
9.2 \\
\end{array}$ & $\begin{array}{c}26 \\
141 \\
26\end{array}$ & $\begin{array}{l}13.5 \\
73.1 \\
13.5\end{array}$ & $\begin{array}{c}5 \\
20 \\
6\end{array}$ & $\begin{array}{l}16.1 \\
64.5 \\
19.4\end{array}$ & $\begin{array}{l}5.777 \\
0.216\end{array}$ \\
\hline
\end{tabular}

* Significant at $\mathrm{P}<0.05$.

Table (7): Shows the correlation between socio-demographic characteristics of the studied women and their total knowledge score regarding fetal movement. It was presented that there was significant relationship between women's level of education, maternal occupation and their total knowledge score regarding fetal movement. It was also noticed that there was no a significant relationship between age, residence, family income of the studied women and their total knowledge score regarding fetal movement. 
Table (8): Correlation between an obstetric history of the studied women and their total knowledge score of fetal movement

\begin{tabular}{|c|c|c|c|c|c|c|c|}
\hline \multirow{3}{*}{ Obstetric history } & \multicolumn{6}{|c|}{ Total knowledge score } & \multirow{3}{*}{$\begin{array}{l}\chi^{2} \\
P\end{array}$} \\
\hline & \multicolumn{2}{|c|}{$\begin{array}{c}\text { Poor } \\
(n=76)\end{array}$} & \multicolumn{2}{|c|}{$\underset{(n=193)}{\text { Fair }}$} & \multicolumn{2}{|c|}{$\begin{array}{c}\text { Good } \\
(n=31)\end{array}$} & \\
\hline & $\mathbf{N}$ & $\%$ & $\mathbf{N}$ & $\%$ & $\mathbf{N}$ & $\%$ & \\
\hline $\begin{array}{l}\text { Smoking during pregnancy: } \\
\text { - } \quad \text { Yes } \\
\text { - } \quad \text { No }\end{array}$ & $\begin{array}{c}5 \\
71\end{array}$ & $\begin{array}{c}6.6 \\
93.4\end{array}$ & $\begin{array}{c}4 \\
189\end{array}$ & $\begin{array}{c}2.1 \\
97.9\end{array}$ & $\begin{array}{c}2 \\
29\end{array}$ & $\begin{array}{c}6.5 \\
93.5\end{array}$ & $\begin{array}{l}3.894 \\
0.143\end{array}$ \\
\hline \begin{tabular}{ll}
\multicolumn{2}{l}{ Parity } \\
- & Null \\
- & $1-3$ \\
& $4-6$
\end{tabular} & $\begin{array}{l}19 \\
46 \\
11\end{array}$ & $\begin{array}{l}25.0 \\
60.5 \\
14.5\end{array}$ & $\begin{array}{c}62 \\
124 \\
7\end{array}$ & $\begin{array}{c}32.1 \\
64.2 \\
3.6\end{array}$ & $\begin{array}{c}14 \\
17 \\
0\end{array}$ & $\begin{array}{c}45.2 \\
54.8 \\
0.0\end{array}$ & $\begin{array}{l}16.061 \\
0.003 *\end{array}$ \\
\hline $\begin{array}{l}\text { Gestational age (weeks) } \\
\text { - } \quad<32 \\
\text { - } \quad \geq 32 \text { years }\end{array}$ & $\begin{array}{l}51 \\
25\end{array}$ & $\begin{array}{l}67.1 \\
32.9 \\
\end{array}$ & $\begin{array}{l}95 \\
98\end{array}$ & $\begin{array}{l}49.2 \\
50.8\end{array}$ & $\begin{array}{l}19 \\
12\end{array}$ & $\begin{array}{l}61.3 \\
38.7\end{array}$ & $\begin{array}{c}7.598 \\
0.022 *\end{array}$ \\
\hline $\begin{array}{ll}\text { Time of initial antenatal care visit } \\
\text { - } & \text { First trimester } \\
\text { - } & \text { Second trimester } \\
\text { - } & \text { Third trimester }\end{array}$ & $\begin{array}{c}63 \\
6 \\
7\end{array}$ & $\begin{array}{c}82.9 \\
7.9 \\
9.2\end{array}$ & $\begin{array}{c}169 \\
19 \\
5\end{array}$ & $\begin{array}{c}87.6 \\
9.8 \\
2.6\end{array}$ & $\begin{array}{c}27 \\
4 \\
0\end{array}$ & $\begin{array}{c}87.1 \\
12.9 \\
0.0\end{array}$ & $\begin{array}{l}8.086 \\
0.088\end{array}$ \\
\hline \begin{tabular}{ll}
\multicolumn{2}{l}{ Number of antenatal visits } \\
- & Once \\
- & Twice \\
- & Three times \\
- & Four times \\
- & More than four
\end{tabular} & $\begin{array}{c}6 \\
14 \\
22 \\
5 \\
29\end{array}$ & $\begin{array}{c}7.9 \\
18.4 \\
28.9 \\
6.6 \\
38.2\end{array}$ & $\begin{array}{c}10 \\
13 \\
24 \\
9 \\
137\end{array}$ & $\begin{array}{c}5.2 \\
6.7 \\
12.4 \\
4.7 \\
71.0\end{array}$ & $\begin{array}{c}3 \\
0 \\
0 \\
2 \\
26\end{array}$ & $\begin{array}{c}9.7 \\
0.0 \\
0.0 \\
6.5 \\
83.9\end{array}$ & $\begin{array}{c}39.396 \\
0.00 *\end{array}$ \\
\hline \begin{tabular}{ll}
\multicolumn{2}{l}{ Planned pregnancy } \\
- & No \\
- $\quad$ Yes
\end{tabular} & $\begin{array}{l}19 \\
57\end{array}$ & $\begin{array}{l}25.0 \\
75.0\end{array}$ & $\begin{array}{c}44 \\
149\end{array}$ & $\begin{array}{l}22.8 \\
77.2\end{array}$ & $\begin{array}{c}7 \\
24\end{array}$ & $\begin{array}{l}22.6 \\
77.4\end{array}$ & $\begin{array}{l}0.159 \\
0.924\end{array}$ \\
\hline
\end{tabular}

* Significant at $P<0.05$.

Table (8): Presents the correlation between an obstetric history of the studied women and their total knowledge score of fetal movement. It shows that there was a significant relationship between women's parity, gestational age, the number of antenatal care visits and their total knowledge score regarding fetal movement. It was also noticed that there was no significant relationship between women's smoking habit, time of initial antenatal care visits if the pregnancy was planned or not and their total knowledge score regarding fetal movement.

Table (9): Correlation between socio-demographic characteristics of the studied women and their action in case of unusual fetal movement.

\begin{tabular}{|c|c|c|c|c|c|}
\hline \multirow{3}{*}{$\begin{array}{l}\text { Sociodemographic } \\
\text { characteristics }\end{array}$} & \multicolumn{4}{|c|}{ Action } & \multirow{3}{*}{$\begin{array}{l}\chi^{2} \\
P\end{array}$} \\
\hline & \multicolumn{2}{|c|}{$\begin{array}{c}\text { Wrong action } \\
(n=264)\end{array}$} & \multicolumn{2}{|c|}{$\begin{array}{c}\text { Right action } \\
(n=36)\end{array}$} & \\
\hline & $\mathbf{N}$ & $\%$ & $\mathbf{N}$ & $\%$ & \\
\hline $\begin{array}{l}\text { Age in years } \\
-\quad<35 \text { years } \\
\text { - } \quad \geq 35 \text { years }\end{array}$ & $\begin{array}{c}241 \\
23 \\
\end{array}$ & $\begin{array}{c}91.3 \\
8.7\end{array}$ & $\begin{array}{c}33 \\
3\end{array}$ & $\begin{array}{l}91.7 \\
8.3\end{array}$ & $\begin{array}{l}0.006 \\
0.940\end{array}$ \\
\hline \begin{tabular}{ll}
\multicolumn{2}{l}{ Marital status } \\
- & Married \\
- & Divorced \\
- & Widow
\end{tabular} & $\begin{array}{c}261 \\
1 \\
2\end{array}$ & $\begin{array}{c}98.9 \\
0.4 \\
0.8\end{array}$ & $\begin{array}{c}36 \\
0 \\
0\end{array}$ & $\begin{array}{c}100.0 \\
0.0 \\
0.0\end{array}$ & $\begin{array}{l}0.413 \\
0.813\end{array}$ \\
\hline \begin{tabular}{lc}
\multicolumn{2}{l}{ Residence } \\
- & Urban \\
- & Rural
\end{tabular} & $\begin{array}{c}99 \\
165\end{array}$ & $\begin{array}{l}37.5 \\
62.5\end{array}$ & $\begin{array}{l}25 \\
11\end{array}$ & $\begin{array}{l}69.4 \\
30.6\end{array}$ & $\begin{array}{c}13.332 \\
0.00 *\end{array}$ \\
\hline \begin{tabular}{ll}
\multicolumn{2}{l}{ Educational level } \\
- & Illiterate \\
- & Reads and writes \\
- & Primary / Preparatory \\
- & secondary/technical diploma \\
- & university
\end{tabular} & $\begin{array}{c}12 \\
19 \\
28 \\
98 \\
107\end{array}$ & $\begin{array}{c}4.5 \\
7.2 \\
10.6 \\
37.1 \\
40.5\end{array}$ & $\begin{array}{c}2 \\
2 \\
2 \\
14 \\
16\end{array}$ & $\begin{array}{c}5.6 \\
5.6 \\
5.6 \\
38.9 \\
44.4\end{array}$ & $\begin{array}{l}1.144 \\
0.887\end{array}$ \\
\hline \begin{tabular}{ll}
\multicolumn{2}{l}{ Maternal occupation } \\
- & No \\
- $\quad$ Yes
\end{tabular} & $\begin{array}{c}193 \\
71\end{array}$ & $\begin{array}{l}73.1 \\
26.9\end{array}$ & $\begin{array}{l}22 \\
14\end{array}$ & $\begin{array}{l}61.1 \\
38.9\end{array}$ & $\begin{array}{l}2.245 \\
0.134\end{array}$ \\
\hline $\begin{array}{ll}\text { Family income } \\
\text { - } & \text { Not enough } \\
\text { - } & \text { Enough } \\
\text { Enough and reserve }\end{array}$ & $\begin{array}{c}42 \\
193 \\
29\end{array}$ & $\begin{array}{l}15.9 \\
73.1 \\
11.0\end{array}$ & $\begin{array}{c}7 \\
19 \\
10\end{array}$ & $\begin{array}{l}19.4 \\
52.8 \\
27.8\end{array}$ & $\begin{array}{l}8.967 \\
0.011 *\end{array}$ \\
\hline
\end{tabular}

* Significant at $\mathrm{P}<0.05$. 
Table (9): Presents the correlation between socio-demographic characteristics of the studied women and their action in case of unusual fetal movement. It illustrates that there was a significant relationship between women's residence, family income and their action in case of unusual fetal movement. The table reveals that there was no significant relations between women's age, educational level, maternal occupation and their action in case of unusual fetal movement.

Table (10): Correlation between an obstetric history of the studied women and their action in case of unusual fetal movement.

\begin{tabular}{|c|c|c|c|c|c|}
\hline \multirow{3}{*}{ Obstetric history } & \multicolumn{4}{|c|}{ Action } & \multirow{3}{*}{$\begin{array}{l}\chi^{2} \\
P\end{array}$} \\
\hline & \multicolumn{2}{|c|}{$\begin{array}{c}\text { Wrong action } \\
(n=264)\end{array}$} & \multicolumn{2}{|c|}{$\begin{array}{c}\text { Right action } \\
\quad(n=36)\end{array}$} & \\
\hline & $\mathbf{N}$ & $\%$ & $\mathbf{N}$ & $\%$ & \\
\hline $\begin{array}{l}\text { Smoking during pregnancy: } \\
\text { - } \\
\text { - } \quad \text { Nos }\end{array}$ & $\begin{array}{c}10 \\
254\end{array}$ & $\begin{array}{c}3.8 \\
96.2\end{array}$ & $\begin{array}{c}1 \\
35\end{array}$ & $\begin{array}{c}2.8 \\
97.2\end{array}$ & $\begin{array}{l}0.092 \\
0.762\end{array}$ \\
\hline $\begin{array}{ll}\text { Parity } & \\
\text { - } & \text { Null } \\
\text { - } & 1-3 \\
& 4-6\end{array}$ & $\begin{array}{c}82 \\
164 \\
18\end{array}$ & $\begin{array}{c}31.1 \\
62.1 \\
6.8\end{array}$ & $\begin{array}{c}13 \\
23 \\
0\end{array}$ & $\begin{array}{c}36.1 \\
63.9 \\
0.0\end{array}$ & $\begin{array}{l}2.726 \\
0.256\end{array}$ \\
\hline $\begin{array}{l}\text { Gestational age (weeks) } \\
\text { - } \\
\text { - } \quad \geq 32 \\
\end{array}$ & $\begin{array}{l}149 \\
115\end{array}$ & $\begin{array}{l}56.4 \\
43.6 \\
\end{array}$ & $\begin{array}{l}16 \\
20 \\
\end{array}$ & $\begin{array}{l}44.4 \\
55.6 \\
\end{array}$ & $\begin{array}{l}1.842 \\
0.175\end{array}$ \\
\hline $\begin{array}{ll}\text { Time of initial antenatal care visit } \\
\text { - } & \text { First trimester } \\
\text { - } & \text { Second trimester } \\
\end{array}$ & $\begin{array}{c}228 \\
27 \\
9\end{array}$ & $\begin{array}{c}86.4 \\
10.2 \\
3.4\end{array}$ & $\begin{array}{l}31 \\
2 \\
3\end{array}$ & $\begin{array}{c}86.1 \\
5.6 \\
8.3\end{array}$ & $\begin{array}{l}2.636 \\
0.268\end{array}$ \\
\hline $\begin{array}{ll}\text { Number of antenatal visits } \\
\text { - } & \text { Once } \\
\text { - } & \text { Twice } \\
\text { - } & \text { Three times } \\
\text { - } & \text { Four times } \\
\text { - } & \text { More than four }\end{array}$ & $\begin{array}{c}16 \\
22 \\
39 \\
15 \\
172\end{array}$ & $\begin{array}{c}6.1 \\
8.3 \\
14.8 \\
5.7 \\
65.2\end{array}$ & $\begin{array}{c}3 \\
5 \\
7 \\
1 \\
20\end{array}$ & $\begin{array}{c}8.3 \\
13.9 \\
19.4 \\
2.8 \\
55.6\end{array}$ & $\begin{array}{c}2.752 \\
0.60\end{array}$ \\
\hline \begin{tabular}{ll}
\multicolumn{2}{l}{ Planned pregnancy } \\
- & No \\
- & Yes
\end{tabular} & $\begin{array}{c}56 \\
208\end{array}$ & $\begin{array}{l}21.2 \\
78.8\end{array}$ & $\begin{array}{l}14 \\
22\end{array}$ & $\begin{array}{l}38.9 \\
61.1\end{array}$ & $\begin{array}{c}5.534 \\
0.019 *\end{array}$ \\
\hline
\end{tabular}

* Significant at $\mathrm{P}<0.05$.

Table (10): Shows the correlation between an obstetric history of the studied women and their action in case of unusual fetal movement. It was observed that there was a significant relationship between if the pregnancy was planned or not among the studied women and their action in case of unusual fetal movement. It presents that there was no significant relationship between women's smoking habit, parity, gestational age, time of initial antenatal care visits, the number of antenatal care visits and their action in case of unusual fetal movement.

Table (11): Correlation between total knowledge score of the studied women and their action in case of unusual fetal movement.

\begin{tabular}{|c|c|c|c|c|c|c|c|c|c|}
\hline \multirow{3}{*}{ Action } & \multicolumn{8}{|c|}{ Total knowledge score } & \multirow{3}{*}{$\begin{array}{l}\chi^{2} \\
P\end{array}$} \\
\hline & \multicolumn{2}{|c|}{$\begin{array}{c}\text { Poor } \\
(n=110)\end{array}$} & \multicolumn{2}{|c|}{$\begin{array}{c}\text { Fair } \\
(\mathbf{n}=182)\end{array}$} & \multicolumn{2}{|c|}{$\begin{array}{l}\text { Good } \\
(n=8)\end{array}$} & \multicolumn{2}{|c|}{$\begin{array}{c}\text { Total } \\
(\mathbf{n}=\mathbf{3 0 0})\end{array}$} & \\
\hline & $\mathbf{N}$ & $\%$ & $\mathbf{N}$ & $\%$ & $\mathbf{N}$ & $\%$ & $\mathbf{N}$ & $\%$ & \\
\hline $\begin{array}{ll}\text { - } & \text { Wrong action } \\
\text { - } & \text { Right action }\end{array}$ & $\begin{array}{l}97 \\
13\end{array}$ & $\begin{array}{l}88.2 \\
11.8 \\
\end{array}$ & $\begin{array}{c}159 \\
23\end{array}$ & $\begin{array}{l}87.4 \\
12.6 \\
\end{array}$ & $\begin{array}{l}8 \\
0\end{array}$ & $\begin{array}{c}100.0 \\
0.0\end{array}$ & $\begin{array}{c}264 \\
36\end{array}$ & $\begin{array}{l}88.0 \\
12.0\end{array}$ & $\begin{array}{l}1.164 \\
0.559\end{array}$ \\
\hline
\end{tabular}

* Significant at $\mathrm{P}<0.05$.

Table (11): Demonstrates correlation between total knowledge score of the studied women and their action in case of unusual fetal movement. It shows that was no significant relationship between total knowledge score of the studied women and their action in case of unusual fetal movement.

\section{Discussion}

Fetal movement assessment is widely used as a method of routine surveillance of the well- being of unborn babies ${ }^{(19)}$. It reduces the risk of stillbirth, fetal growth restriction, fetal distress and perinatal mortality. Furthermore, the maternal-fetal attachment is increased by fetal movements' perception ${ }^{(11,20,21)}$. Health care providers have long acknowledged the importance of maternally perceived fetal movements, but continue to 
under investigate the maternal perception of fetal activity to date ${ }^{(22,23)}$. Therefore, this study was undertaken to determine the maternal perception of fetal movement and antenatal advice regarding fetal movement. The result of the present study revealed that most of the women in the present study were less than 35 years old, less than half of them had a university education and nearly three-quarters of them were housewives. Also, two-thirds of the studied women had from one to three previous deliveries, the majority of them started the antenatal care during the first trimester, and more than two- thirds of them went more than four times for antenatal follow-up visits.

Regarding the perception of the fetal movement in the present study, fetal movement monitoring was easy and feasible, as illustrated by the fact that more than two-thirds of the studied women reported that it is easy to fell fetal movements. This result agrees with Berndl et al., (2013) ${ }^{(24)}$ and Saastad el al., (2008) ${ }^{(25)}$. While, Malm et al., (2014) ${ }^{(26)}$, indicated that low maternal awareness of fetal movements is associated with negative birth outcomes. The mean gestation for the studied women to perceive first fetal movements was 19 weeks, in accordance with previous researches of the Royal College of Obstetricians and Gynaecologists $(2011)^{(27)}$, and Olesen and Svare (2004) ${ }^{(1)}$. Half of the women in the present study perceived their baby's first action as gentle, but they could not describe the type of the first action. While, Raynes -Greenow et al., (2013) ${ }^{(28)}$, indicated that as pregnancy progressed, women's descriptions of the action included specific limb descriptions and the whole body descriptions. Most women in the present study expressed positive emotional response to feeling their baby's first movement. This may be attributable to that this pregnancy was planned. This result is in accordance with that of Raynes-Greenow et al., $(2013)^{(28)}$.

In the current study, the perception of fetal movement increased in the early morning and during the night. While the greatest number of fetal movements were noted when the woman was lying down. This result was not a surprise as most women in the early morning are not distracted, so fetal movements are easily noticed. This result is in line with Raynes -Greenow et al., (2013) ${ }^{(28)}$. The majority of women in the present study expressed concern about any variations in the fetal movement. While the proportion of women who expressed concern over excessive or decreased fetal movements were nearly half and most of the participants, respectively, suggesting that the decreasing fetal movement may give serious cause of concern to women over the safety of the fetus than excessive fetal movement. This result agrees with the documented evidence that a reduction in fetal activity is often associated with complications of chronic rather than acute non-reassuring fetal status as the compromised fetus decreases its oxygen requirements by reducing activity. While, excessive movements provide reassurance of fetal well- being and oxygenation ${ }^{(16,29,30)}$. On the other hand, several researchers indicated that women who perceive a reduction in fetal movements will have a normal outcome to their pregnancy $^{(4,11,31)}$.

Regarding knowledge of fetal movement, the present study revealed that the majority of the studied women expressed that it is important to feel the fetal movements, and three-quarters of them reasoned that this is an indication that the baby is alive. Pregnant women should understand that fetal movements are significant and that they change during pregnancy, both in number and strength ${ }^{(29)}$. This result agrees with Maputle and Mothiba (2006) ${ }^{(23}$, and Berndl et al., (2013) ${ }^{(24)}$. A considerable proportion of the surveyed women had no clue of the expected normal frequency of fetal movement despite the fact that any alteration in regular fetal activity in the last trimester of pregnancy may be a signal for impending stillbirth. The obtained result is consistent with Maputle and Mothiba (2006) ${ }^{(23)}$, and Olagbuji et al.,(2014) ${ }^{(32)}$. The deeply divided evidence on the frequency of fetal movements in the last trimester of pregnancy account for this consistency ${ }^{27,33)}$. Furthermore, twothirds of the studied women knew that sounds, fetal sleep pattern and maternal activity level affect their perception of fetal movement and most of them knew that smoking and medications affect their perception of fetal movements. The woman's perception of fetal movements is influenced by sounds, drugs, cigarette smoking, fetal sleep state, time of the day, maternal activity level, the presence of obesity, maternal employment, parity, placental position, maternal fasting, and maternal position during counting ${ }^{(29,34,35)}$.

The total knowledge score regarding fetal movement in the present study revealed that about two-thirds of the women had a fair knowledge and only thirty-one women $(10.3 \%)$ had good knowledge regarding fetal movement. Also, Maputle and Mothiba (2006) ${ }^{(23)}$, indicated that the responses from their participants confirm a knowledge deficit on fetal movement. While, according to Berndl et al., (2013) ${ }^{(24)}$, less than half of the women in their study had the right knowledge regarding fetal movement. It seems that the variation in the results could be due to the differences in the type of sampling and scoring system used. Our findings on sources of information about fetal movement are consistent with those of Berndl et al., (2013) ${ }^{(24)}$ Raynes -Greenow et al., (2013) $^{(28)}$, and Olagbuji et al., (2014) ${ }^{(32)}$, which showed that doctors and nurses are the leading sources of information to women about fetal movement. While, the result was inconsistent with Maputle and Mothiba (2006) ${ }^{(23)}$, who indicated that a significant number of mothers (54\%) received information about fetal movement from mothers / significant others which could be inaccurate.

As regard to the action taken in case of unusual fetal movement in the present study, only $12 \%$ of the respondents made the right action. This may be related to the fact that only $2.7 \%$ of our subjects received 
advice about the action that should be taken in case of unusual fetal movement. This result agrees with Raynes Greenow et al.,(2013) ${ }^{(28)}$. While previous researchers found that approximately half of the women with decreased fetal movement waited more than 24 hours before accessing care ${ }^{(23,24)}$. On the other hand, the Royal College of Obstetricians and Gynaecologists' guidelines in the United Kingdom recommended that women who are concerned about reduced fetal movements should not wait until the next day for assessment ${ }^{(27)}$. Of concern, more than one-third of the women in this study received advice about fetal movement at antenatal visits. Also, nearly one-quarter of them were asked regularly about fetal movements. Moreover, only $7.7 \%$ received information about the form of fetal movement. This result disagrees with the studies of Raynes Greenow et al., (2013) ${ }^{(28)}$, Olagbuji et al., (2014) ${ }^{(32)}$, and Peat et al., (2012) ${ }^{(36)}$. Meanwhile, the Australian and New Zealand Stillbirth Alliance (ANZSA) published guidelines regarding fetal movements, which were consistent with the Royal College of Obstetricians and Gynaecologists' guidelines in the United Kingdom ${ }^{(37,27)}$. ANZSA guidelines include giving all pregnant women advice about fetal movements, namely that it is normal to experience at least ten movements in 2 hours and advising women not to wait until the next day if they notice decreased or absent fetal movements ${ }^{(37)}$. Conversely, Saastad el al., (2008) ${ }^{(25)}$, concluded from their study that receiving information about expected fetal activity was associated with maternal concerns about decreased fetal movements, but not with improved outcomes.

In the current study, there was a statistically significant correlation between the educational level of the studied women and the total knowledge score regarding fetal movements. This result was incongruent with Berndl et al. (2013) ${ }^{(24),}$ Olagbuji et al., $(2014)^{(32)}$ and Engle and Kominiarek $(2008)^{(38)}$. Berndl et al., (2013) (24), further demonstrated convincingly that maternal right knowledge of fetal movement, a component of "safe baby chin ", is one of the main factors that influence prompt presentation to a health care provider when they face a challenge of decreased fetal movement. In our study, there was no statistically significant correlation between the women's total knowledge score regarding fetal movement and the action that should be taken in case of unusual fetal movement. One possible explanation is that women may be picking up the underlying message from society that technology is better at assessing their baby's well- being than they are which may decrease women's confidence in their own knowledge and ability to assess fetal condition. The result of Olagbuji et al., (2014) ${ }^{(32)}$, confirm the present study results.

\section{Conclusion}

In conclusion, one-quarter of the studied women exhibited poor knowledge regarding fetal movement, most of them made the wrong action in case of unusual fetal movements, and about two-thirds of them did not receive any advice about fetal movements during routine antenatal care. There was a significant relationship between women's level of education, employment, parity, gestational age, the number of antenatal care visits and their total knowledge score regarding fetal movement. Also, there was significant relationship between women's residence, family income and their action in case of unusual fetal movement. While there was no significant relationship between total knowledge score of the studied women and their action in case of unusual fetal movement.

\section{Recommendations}

The results of the present study reflect the need for increasing maternal awareness about fetal movements and the action that should be taken in case of unusual fetal movements through antenatal classes, pamphlet and mass media, particularly during antenatal care. Also, reinforcing the significance of maternal perception of fetal movement for the health care providers through refreshing courses and in-service training. Further studies are needed in this field to assess; health care providers' knowledge and practices regarding fetal movement assessments, and the effect of health education program on women's knowledge and practices regarding fetal movement.

\section{References}

[1]. Olesen AG. \& Svare JA. Decreased fetal movements: background, assessment, and clinical management. Acta Obstet Gynecol Scand 2004; 83(9):818-26.

[2]. Singh LT, Col G. \& Sidhu MK. Daily fetal movement count chart: reducing perinatal mortality in low-risk pregnancy. Medical Journal Armed Forces India (MJAFI) 2008; 64: 212-213.

[3]. Mangesi L, Hofmeyr GJ. \& Smith V. Fetal movement counting for assessment of fetal wellbeing. Cochrane Database of Syst Rev 2015; 15 (10):CD004909. doi: 10.1002/14651858.CD004909.pub3.

[4]. Haezell AE, Sumathi GM. \& Bhatti NR. What investigation is appropriate following maternal perception of reduced fetal movements? J Obstet Gynaecol 2005; 25:648-650.

[5]. Editorial. Reduced Fetal Movements: Interpretation and Action. The Journal of Obstetrics and Gynecology of India 2011; 2:141143.

[6]. Hijazi ZR. \& East CE. Factors affecting the maternal perception of fetal movement. Obstet Gynecol Surv 2009; 64(7):489-497.

[7]. Heazell AE. \& Frøen JF. Methods of fetal movement counting and the detection of fetal compromise. J Obstet Gynaecol 2008;28(2):147-154. 
[8]. Warland J. \& Glover P. Fetal movements: What are we telling women? Women and Birth 2017; 30: 23-28. http://dx.doi.org/10.1016/j.wombi.2016.06.001

[9]. Sharp GC, Stock SJ, Norman JE. Fetal assessment methods for improving neonatal and maternal outcomes in preterm prelabour rupture of membranes. Cochrane Database Syst Rev. 2014; 10:CD010209. doi: 10.1002/14651858.CD010209.pub2. Review.

[10]. Neonatal and maternal outcomes in preterm prelabour rupture of membranes. Cochrane Database Syst Rev. 2014; 10:CD010209. Doi: 10.1002/14651858. CD010209.pub2. Review.

[11]. O'Sullivan O, Stephen G, Martindale E. \& Heazell AE. Predicting poor perinatal outcome in women who present with decreased fetal movements. J Obstet and Gynaecol 2009; 29: 705-710.

[12]. Tveit JV, Saastad E, Stray-Pedersen B, et al. Maternal characteristics and pregnancy outcomes in women presenting with decreased fetal movements in pregnancy. Acta Obstet Gynecol Scand. 2008a; 88(12):1345-1351.

[13]. Saastad E, Stray-Pedersen B, et al. 2009b. Reduction of late stillbirth with the introduction of fetal movement information and guidelines - a clinical quality improvement. BMC Pregnancy and Childbirth 9,32. http://dx.doi.org/ 10.1186/1471-2393-9-32.

[14]. LiZ Mc, Nally L, Hilder L. \& Sullivan EA. Australia mothers and babies 2009. Perinatal statistics. In: Unit ANPEaS, editor. Perinatal statistics series no. 52, Cat. no. PER 52. Sydney: AIHW National Perinatal Epidemiology and Statistics Unit; 2011.

[15]. Cacciatore J, Schnebly S. \& Frøen JF. The effects of social support on the maternal anxiety and depression after stillbirth. Health Soc Care Community 2009; 17(2): 167-176.

[16]. Dutton PJ, Warrander LK, Roberts SA, et al. Predictors of poor perinatal outcome following maternal perception of reduced fetal movements - a prospective cohort study. PLoS One. 2012; 7:e39784.

[17]. Warland J, Mitchell A. \& O'Brien M. Novel strategies to prevent stillbirth. Seminars in Fetal \& Neonatal Medicine. 2017. An article in press. 1-7. http:// dx.doi.org/10.1016/j.siny.2017.01.005

[18]. McArdle A, Flenady V, Toohill J, Gamble J. \& Creedy D. How pregnant women learn about fetal movements: Sources and preferences for information. Women and Birth. 2015; 28:54-55. http://dx.doi.org/10.1016/j.wombi.2014.10.002

[19]. Frøen JF, Tveit JV, Saastad E, et al. Management of decreased fetal movements. Seminars in Perinatology 2008; 32: 307-311.

[20]. Winje BA, Wojcieszek AM, Gonzalez-Angulo LY, et al. Interventions to enhance maternal awareness of decreased fetal movement: a systematic review. BJOG 2016; 123:886-898.

[21]. Shieh C. \& Kravitz M. Maternal-fetal attachment in pregnant women who use illicit drugs. Journal of Obstetric, Gynecologic, \& Neonatal Nursing 2002; 31(2):156-164.

[22]. Bradford B. Maternal perception of fetal movements: a qualitative description, Master thesis, New Zealand, Victoria University of Wellington, Collage of Midwifery, 2014.

[23]. Maputle MS. \& Mothiba MT. Mothers' knowledge of fetal movements monitoring during pregnancy in relation to perinatal outcome. Health SA Gesondheid 2006; 11(2):13-22.

[24]. Berndl AM. OConnell CM. \& McLeod NL. Fetal movement monitoring: How are we doing as educators? J Obstet Gynaecol Can 2013; 35(1):22-28.

[25]. Saastad E, Ahlbog T. \& Frøen JF. Low maternal awareness of fetal movement is associated with small for gestation age infants. J Midwifery and Women's Health. 2008; 53(4):345-352.

[26]. Malm M, Rådestad I, Rubertsson C, et al. Women's experiences of two different self - assessment methods for monitoring fetal movements in full - term pregnancy -a crossover trial. BMC Pregnancy and Childbirth 2014;14:349.

[27]. Royal College of Obstetricians \& Gynaecologists Green-top Guideline 57 February 2011: Reduced Fetal Movements. Retrieved from http//www.nice.org.uk/womens -health /clinical-guidance/reduced-fetal-movements-green-tops-57 available at 13/7/2016.

[28]. Raynes -Greenow CH, Gordon A, Li Q. \& Hyett JA. Across-sectional study of maternal perception of fetal movements and antenatal advice in a general pregnant population, using a qualitative framework. BMC Pregnancy and Childbirth 2013; 13:32.

[29]. Davidson M, London $M$ and Ladewig P.OLDS' Maternal-Newborn Nursing \& Women's Health, A cross the Lifespan. $9^{\text {th }}$ ed., Pearson, Boston, 2012; 358-60.507.

[30]. Stacey T, Thompson JM, Mitchell EA, et al. Maternal perception of fetal activity and late stillbirth risk: Findings from the Auckland Stillbirth Study. BIRTH 2011; 38(4):311-316.

[31]. Sinha D, Sharam A, Nallaswamy V, et al. Obstetric outcome in women complaining of reduced fetal movement. J Obstet Gynaecol 2007; 27:41-43.

[32]. Olagbuji BN, Igbarumah S, Akintayo AA, et al. Maternal understanding of fetal movement in the third trimester: A means for monitoring and reducing stillbirth. Nigerian Journal of Clinical Practice 2014; 17(4):489-494.

[33]. Saastad E, Winje BA, Stray Pederson B. \& Frøen JF. Fetal movement counting improved identification of fetal growth restriction and perinatal outcomes: A multi-center, randomized, controlled trial. PLoS One 2011; 6(12):e28482.

[34]. Sheikh M, Hantoushzadeh S. \& Shariat M. Maternal perception of decreased fetal movements from maternal and fetal perspectives, a cohort study.BMC Pregnancy and Childbirth 2014; $14: 286$.

[35]. Aviram A, Shmueli A, Hiersch L, et al .Pregnancy outcome in women with decreased sensation of fetal movements at term according to parity. BIRTH 2016; 43:42-48.

[36]. Peat A, Stacey T, Cronin R. \& McCowan L. Maternal knowledge of fetal movements in late pregnancy. ANZJOG 2012 DOI $: 10.1111 / \mathrm{j} .1479-828 \mathrm{X} .2012 .01462 . \mathrm{X}$

[37]. Preston SMK, Mahomad K, Chadha Y, et al. for the Australian and New Zealand Stillbirth Alliance (ANZSA) .Clinical Practice Guideline for the Management of Women who Reported Decreased Fetal Movements. Brisbane: ANZSA, 2010.

[38]. Engle WA. \& Kominiarek MA. Late preterm infants, early term infants, and timing of elective deliveries .Clin Perinatol 2008; 35(2):325-341. 